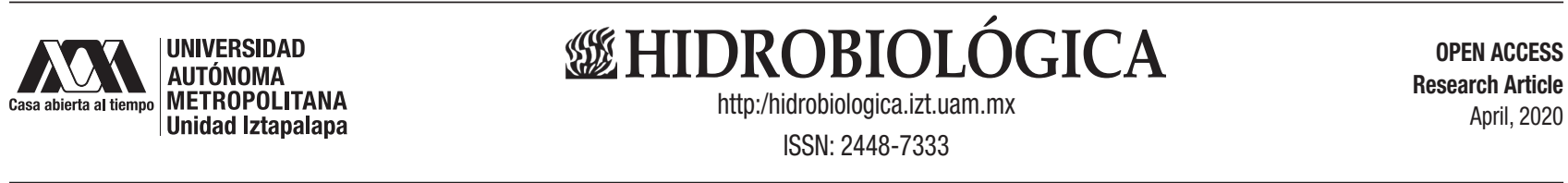

\title{
Gonadal histology of Erichsonella attenuata( (Isopoda: Valvifera: Idoteidae)
}

Histología gonadal de Erichsonella attenuata (Isopoda: Valvifera: Idoteidae)

Hugo Enrique Reyes-Aldana ${ }^{1,2} \odot$, Adriana Muñoz-Hernández ${ }^{3}$ y José Luis Bortolini-Rosales ${ }^{4}$

Faculty of Biology, Ludwig-Maximilians-Universität München. Großhaderner Str. 2,Planegg-Martinsreid, 82152 Germany.

2 Rachel Carson Center, Ludwig-Maximilians-Universität München. Leopoldstraße 11A, Munich, 80802. Germany.

${ }^{3}$ Cellular Biology Department, Faculty of Sciences, National Autonomous University of Mexico. University Avenue 3000 Exterior Circuit, Coyoacán Delegation, University City, CDMX, 04510. Mexico.

${ }^{4}$ Comparative Biology Department, Faculty of Sciences, National Autonomous University of Mexico. University Avenue 3000, Exterior Circuit, Coyoacán Delegation, University City, CDMX, 04510 Mexico.

*Corresponding author: Hugo Enrique Reyes-Aldana: e-mail: hugoraldana@ciencias.unam.mx

To quote as:

Reyes-Aldana H. E., A. Muñoz-Hernández \& J. L. Bortolini-Rosales. 2020. Gonada histology of Erichsonella attenuata (Isopoda: Valvifera: Idoteidae. Hidrobiológica 30 (1) 29-36.

DOl: 10.24275/uam/iz/dcbs/hidro/2020v30n1/ Reyes

\section{ABSTRACT}

Background: Isopods are highly diverse organisms, however, despite of their abundance and importance in ecological dynamics have been neglected in many of the aspects of their biology. Objectives: This paper analyses $E$. attenuata male and female histological characteristics, especially the reproductive structures, to increase the information of the reproductive biology and help to understand the sexual characteristics of other free-living isopods to favour comparative studies with other groups and environmental conditions. Methods: Organisms sampled between July 2010 and August 2011 were fixed and processed for histological preparations; Haematoxylin-Eosin and Lendrum staining techniques were applied to differentiate structures. Microphotographies were taken and analysed. Results: The internal organography was found to be similar on both sexes. The ovaries are modified during the maturation of the oocytes, after spawning, embryos are born in the marsupium. In some cases, a cohort in initial stages of maturation is observed in the dorsal region of the body in addition of the ones seen in the marsupium. A couple of testicles, comprising three cysts and in which different cell stages of spermatogenesis can be found, are observed in males. Conclusions: Since maturation of gametes occurs during the whole year, it is concluded that $E$. attenuata has a continuous reproductive cycle. We describe for the first time the reproductive characteristics of this isopod, which is important as reproductive aspects of these crustaceans have been neglected, thus, it is necessary to update and extend the morphological and histological information.

Keywords: Isopod, ovaries, reproduction, testicles

\section{RESUMEN}

Antecedentes: Los isópodos son organismos altamente diversos, sin embargo, a pesar de su diversidad e importancia en la dinámica ecológica, han sido desantendidos en muchos aspectos de su biología. Objetivos: Se analizan las características histológicas de machos y hembras de E. attenuata, especialmente las estructuras reproductivas para incrementar la información de la biología reproductiva y ayudar a entender las características sexuales de otros isópodos de vida libre para favorecer estudios comparativos con otros grupos y condiciones ambientales. Métodos: Organismos muestreados entre julio del 2010 y agosto del 2011 fueron fijados y procesados para preparaciones histológicas; se utilizaron técnicas de Hematoxilina-Eosina y Lendrum para diferenciar estructuras. Se tomaron y analizaron microfotografías. esultados: La organografía interna es similar en ambos sexos. Los ovarios se modifican durante la maduración de los oocitos, después de la puesta, los embriones nacen en el marsupio. En algunos casos, una cohorte en estados iniciales de maduración se observa en la región dorsal del cuerpo, además de los que se presentan en el marsupio. Los machos presentan un par de testículos, con tres cistos, en los cuales se encuentran diferentes estadios de la espermatogénesis. Conclusiones: Como la maduración de los gametos ocurre durante todo el año, se concluye que $E$. attenuata presenta una reproducción continua. Se describe por primera vez las características reproductivas de este isópodo, lo que es importante porque los aspectos reproductivos de estos crustáceos han sido descuidados, por ello, es necesario actualizar y extender la información histológica y citológica.

Palabras clave: isópodo, ovarios, reproducción, testículos 


\section{INTRODUCTION}

Crustaceans represent the second most diverse group within the arthropods encompassing approximately 70,000 described species and even a greater number is expected to be described (Brusca et al., 2016).

Erichsonella attenuata (Harger, 1873) is a free-living marine organism, dominant in some regions of the western of the Atlantic Ocean, in the Gulf of Mexico and commonly associated to several species of sea grasses (Kensley et al., 1995; Poore \& Schotte, 2014) (Fig. 1). E. attenuata inhabits shallow waters of tropical and temperate regions, preferring sites with algae, muddy plains, seagrass and substrate with remains of shells. This species can be readily distinguished because its maximum body length is $2.92 \mathrm{~cm}$, its head is on average two times wider than its body length, the non-pedunculated eyes are positioned laterally, on average adult males are larger than females, its colour varies from amber to brown, and both sexes may have dark spots in the dorsal and ventral surfaces (Pirés, 1984; Bortolini-Rosales et al. 2016). The species of seagrass beds to which $E$. attenuata is associated are mainly Ruppia maritima (Linnaeus, 1753), Zostera marina (Linnaeus, 1753), Halodule wrightii (Ascherson, 1868) and Thalassia testidinum (Banks ex König, 1805) (Ryer \& Orth, 1987; Fredette et al., 1990; Kensley et al., 1995; Boström \& Mattila, 2005).

From a biological and ecological perspective, reproduction is a costly process involving the investment of a large percentage of energy resources. The understanding of the gonadic cycle of a species could be a reference of the participation of that species in the trophic chain (Kautsky, 1982; Encina \& Granado-Lorencio, 1997; Johnson et al., 2001).

In the case of economically important species, the reproductive cycle can be used to calculate the production during the different seasons of the year. However, for non-commercial species this can serve to monitor the health condition of the populations and associated ecosystems (Kautsky, 1982), which is the case for E. attenuata. This organism is important within the trophic chain, because it serves as food for larvae and juvenile stages of fish and other crustacean species of economic and ecological relevance, such as Sygnathus fuscus (Ryer \& Orth, 1987).

Studies about growth of crustaceans related to change in external morphology, histological, biochemical and histochemical changes associated with moult have been conducted, but little attention has been given to changes in the physiology, internal structure, and histochemistry occurring throughout their life-cycle (Holdich, 1971). Although the literature offers information about the effects of parasitic castration, damage in development of the gonads of the host in epicaridean and free-living isopods such as $E$. attenuata, information about its reproductive biology is rare (Romero-Rodríguez \& Román-Contreras, 2008). In general, within the isopods there are two sorts of reproductive strategies, the first one is known as discrete or seasonal, and the second one as continuous or non-seasonal (Warburg, 2013). Since there is a reduced scientific production on the histological traits of different groups of crustaceans, particularly Isopoda, the present study provides information about the histologic characteristics of the reproductive system of $E$. attenuata for both sexes. The further development this information could make possible to gain new insights of the evolutionary develop- ment of sexual structures in different groups of crustaceans through the comparison with other species to understand if ecological and reproductive conditions favoured certain kind of adaptations or they are product of other evolutionary processes.

\section{MATERIAL AND METHODS}

Seven bimonthly collections were conducted between July 2010 and August 2011 in Tamiahua Lagoon, Veracruz (Bortolini-Rosales et al., 2016) (Fig. 1). Benthos samples associated with marine vegetation and substrate were obtained and processed with sieves of 1.6 and $2.0 \mathrm{~mm}$ of mesh size. Samples were placed in plastic bags and then placed into a cooler with ice, according to Johnson (1980), when samples reached on average $5-6^{\circ} \mathrm{C}$, a subsample was fixed with Davidson's solution and the remaining was conserved on $\mathrm{EtOH} 70 \%$, finally, biological material was transported to the laboratory. The samples were washed with running water for 6 hours as recommended by Bell \& Lightner (1988), and subsequently the organisms were manually separated from the rest of the organic matter and both subsamples were preserved in EtOH 70\% for histological studies.

The organisms were sexed; those bearing hemi-penis and stylet were considered males, whereas organisms lacking these structures were considered females (Fig. 2).

For the histological studies, 92 isopods (46 ơ o and 46 우 우 ) of all sizes, of each collection event were selected. The organisms were placed in cassettes for biopsy, dehydrated sequentially and cleared in xylene before paraplast embedding $\left(56-58^{\circ} \mathrm{C}\right.$ melting point) (Bell \& Lightner, 1988; Alvarez et al., 2010).

Longitudinal and transversal sections with 5-7 $\mu \mathrm{m}$ of thickness were done with a rotatory microtome (Leica RM2125RT). Two staining techniques were applied: Hematoxilin-Eosin $(\mathrm{H}-\mathrm{E})$, which allowed observing in overview the structures and the Lendrum technique, which allows differentiating genetic material (Sheehan \& Hrapchak, 1980; Austin \& Austin, 1989).

Once dried, the histological slides, were observed in an optical microscope Zeiss Axiostar at different magnifications (10X, 40X and 100X), photomicrographies were produced with an Olympus EVOLUTION-MP camera of 6 megapixels.

\section{RESULTS}

Three hundred and eighty-eight histological slides were obtained corresponding to 144 ᄋ $ᄋ$ and $194 \sigma^{7} \sigma^{7}$, from which 196 microphotographies were captured (102 from $\sigma^{\prime} \sigma^{\prime}$ and 94 from $\$$ 우 ). Differences between genitalia of males and females of $E$. attenuata are evident, in females, paired gonopores are located in the sixth thoracic segment (Fig. 2A), while males show hemipenis between the end of the last segment and the most anterior part of the pleon (Fig. 2B-C),at the end of the hemipenis and the dorsal part, small furrow can be observed, those furrows are the structures that allow the ejection of the sperm (Fig. 2C). An important part of the male reproductive system are the stylets, paired longitudinal structures with ornamentation located next to the second pair of pleopods (Fig. 2D), those structures penetrate the gonopores and conduct the sperm to the female cavity. 


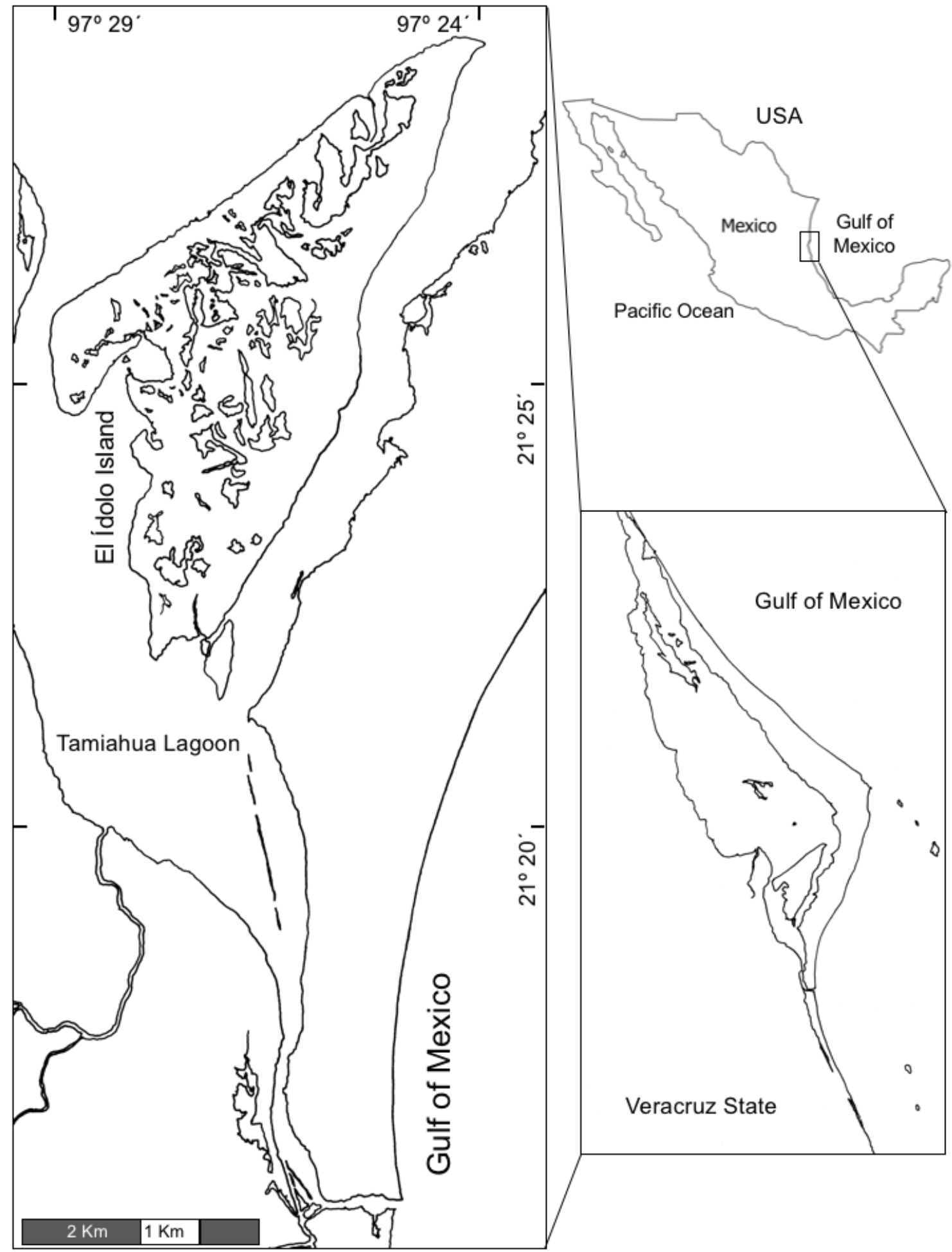

Figure 1. Map of Idolo Island and Tamihaua Lagoon in the State of Veracruz, Mexico. 

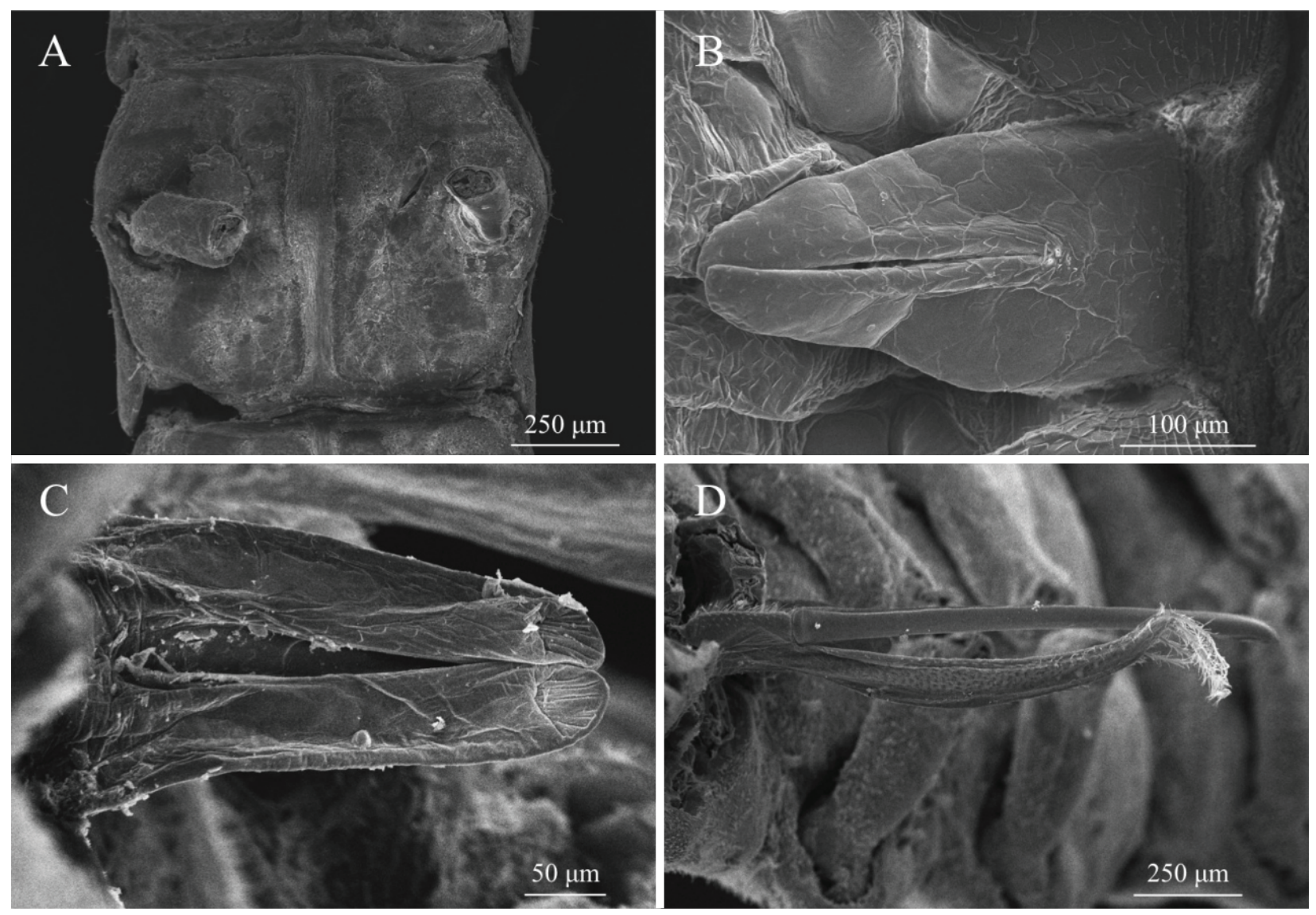

Figure 2.- Masculine and feminine genitalia of $E$. attenuata. A, Female gonopore located in the sixth thoracic segment; $\mathrm{B}$, Anterior region of the hemipenis; C, Posterior region of the hemipenis; D, Left stylet on the second pleopod.

The gonads are paired structures in the dorsal region of the body in both sexes. The digestive tract is surrounded by six hepatopancreatic tubules and in the ventral zone one can find the longitudinal cords of the nervous system, all these organs are surrounded by conjunctive tissue and muscle in different dispositions; the most external layer correspond to the cuticle (Fig. 3A). Females exhibit, in intermediate and advanced stages, the development of oosteguites, these structures are the precursors of the marsupium that will accommodate the embryos in advanced stages (Fig. 3E-F). The most notable change in the gonads was the increase in size of oocytes at maturation, which lead to a compression of the hepatopancreas, the hemal and digestive systems. Cohorts of oocytes in maturation and follicles in latency were observed along the ovaries in all organisms from all sizes and collecting dates, the follicles were adjacent to the cohorts of maturing oocytes. In the case of females in post-spawning stage, while a generation is allocated in the marsupium, another cohort of oocyte is maturing inside the body of the female.

The testes are organized as a pair of testicles located dorsally (Fig. 4A). This pair of testicles is compartmentalized in regions or cysts, in which different phases of the germline develop (Fig. 4B). This compartmentalization shows a maturation of the germline in a longitudinal form, which begins with the most basal stages in the posterior region of the organism and a progression to the anterior region, in which one can find the hemipenis from which the mature spermatozoids will be ejaculated. By recognizing different phases of the spermatogenesis along the testes we identified three regions: incipient testicle $\left(T^{1}\right)$, intermediate $\left(T^{2}\right)$ and advanced $\left(T^{3}\right)$ per.

In larger magnifications, the presence of specific cell populations in the testes can be observed: spermatogonia, primary and secondary spermatocytes, spermatids and spermatozoids. Accessory cells (Cac) make up the perimeter of the different sectors of the testicles, unlike the females in where the follicles $(F)$ change in size and shape, the Cac do not change in size or shape regarding to the testicular region.

\section{DISCUSSION}

We confirm Wilson (1991) and Schuldt (1993) observations of marine isopod organography patterns in $E$. attenuata, having a pair of testicles positioned longitudinally, opening at the gonopores that are located towards the back of the body. Furthermore, the female ovaries are located dorsally with the gonopore located in the sixth segment (thorax), which are oval and paired. An epithelial membrane resembling a pearl necklace forms the ovaries and on which follicular cells, developing follicles and developing oocytes are anchored, (Shyamasundari et al., 1987; Wilson, 1991; Jaglarz et al., 2014). 
A
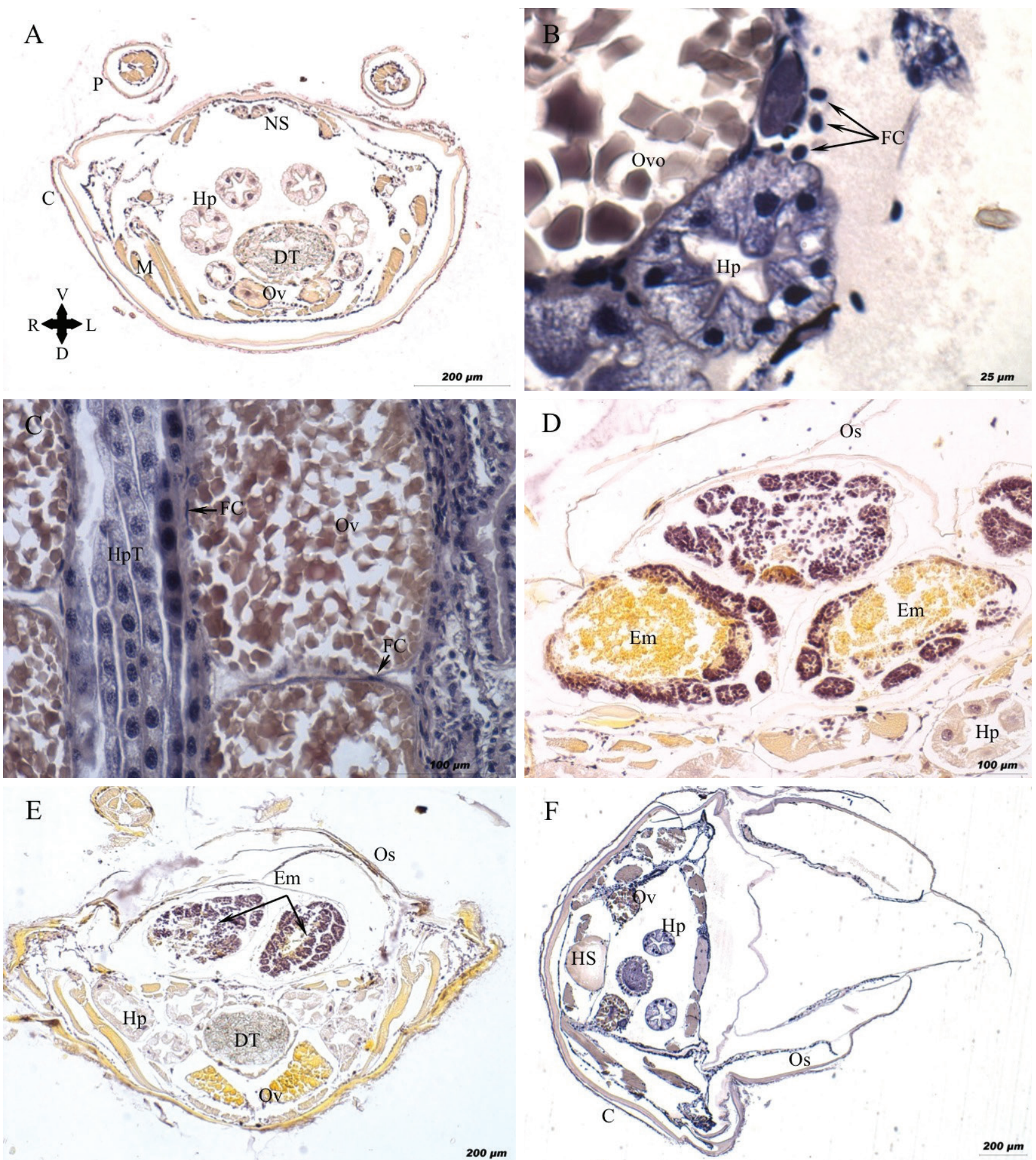

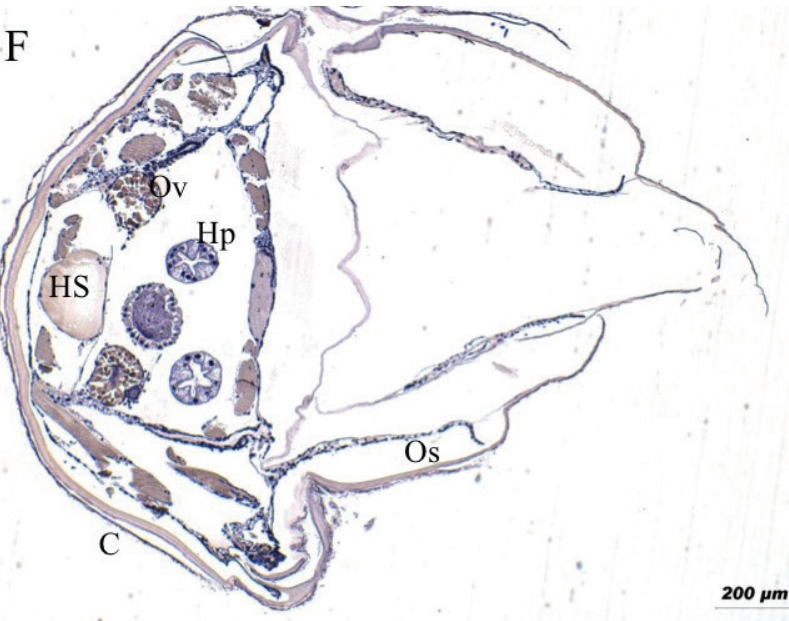

Figure 3.- Cross arrow shows the position of the organism in the cut. R, rigth-side; L, left-side; D, dorsal and V, ventral region.Female histology of $E$. attenuata. A, transversal cut of ovaries in medial development showing six well-developed hepatopancreatic tubes with a central lumen without displacement due to the development of oocytes. B, detail of oocytes in advanced stage and in initial stage aside of a hepatopancreatic tubule. Notice that the follicular cells are still spherical. C, hepatopancreas compressed by near-terminal stage oocyte. D, embryos housed in the marsupium. E, embryos located between the osteguites with oocytes of the next generation in the dorsal region of the body. $\mathrm{F}$, embryos within egg, and osteguites available for the following generation. Abbreviations: $A C$, Accessory cells; $C$, Cuticle; DT, Digestive tract; Em, Embryo; FC, Follicular cell; HS, Hemal sinus; Hp, Hepatopancreas; HpT, Hepatopancreatic tubule; M, Muscle; NS, Nervous system; Os, Osteguite; Ov, Ovary; Ovo, Ovocyte; P, Pereiopod. A, D and E, Lendrum technique; B, C and F, H-E technique. 

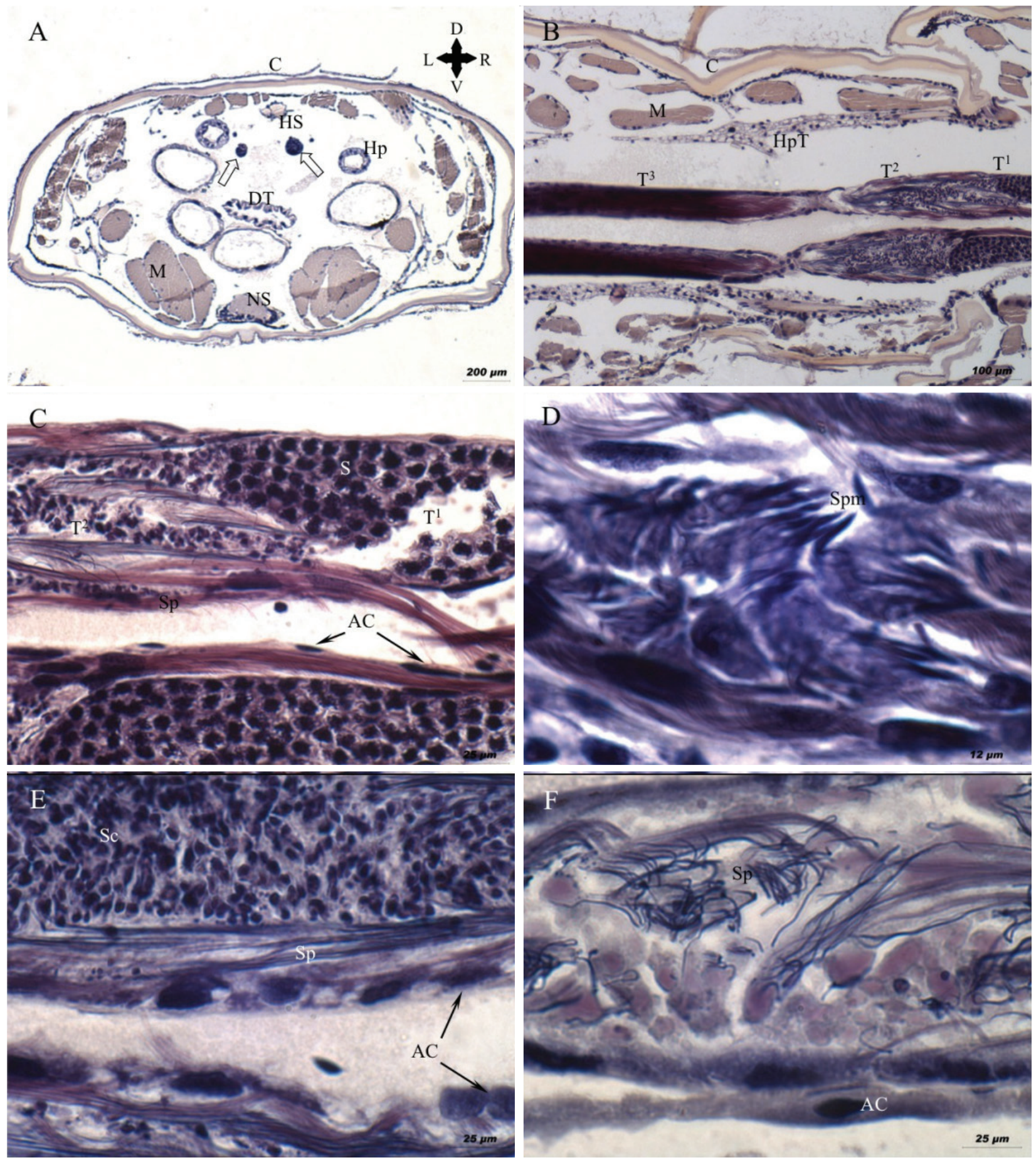

Figure 4.- Cross arrow shows the position of the organism in the cut. R, rigth-side; L, left-side; D, dorsal and V, ventral region.Male histology of $E$. attenuata. A, panoramic view showing the location of the main internal organs; the circulatory system in the dorsal region, the nervous system in the ventral region, three pairs of hepatopancreas tubes and digestive tract in the middle region, testicles in the dorsal region of the organisms (Empty arrows). B, compartmentalization of the testicles according sperm development: $\mathrm{T}^{1}$, Initial Testicle; $\mathrm{T}^{2}$, Intermediate Testicle and $\mathrm{T}^{3}$, Terminal Testicle; the hepatopancreas tubes and muscle packages associated with the cuticle can be observed. C, detail of the testis in their initial or incipient portion, populations of spermatogonia and primary spermatocytes. D, region of transition from intermediate to advanced where spermatids are in the process of spermiogenesis; $E$, spermatocytes and spermatids with some spermatozoids. $F$, terminal region where there are mostly well-defined spermatozoids and on the verge of being expelled. Abbreviations: AC, Accesory cells; C, Cuticle; DT, Digestive tract; Empty arrows, Testicles; HS, Hemal sinus; Hp, Hepatopancreas; HpT, Hepatopancreatic tubule; M, Muscle; NS, Nervous system; S, Spermatogonia; Sc, Spermatocites (First and second); Sp, Spermatozoa; Spm, Spermatids; $\mathrm{T}^{1}, ; \mathrm{T}^{2}, ; \mathrm{T}^{3}, . \mathrm{A}-\mathrm{F}, \mathrm{H}-\mathrm{E}$ technique. 
Ovigerous females, carried at least two generations of oocytes at different stages, i.e. embryos in the marsupium (Csonka et al, 2015) and oocytes inside of the ovaries which suggest the continuity in the reproduction of the species throughout an annual cycle, and the coexistence of at least two generations or potential three generations in a single female at a time.

The literature indicates that most free-living isopods possess three pairs of testicles, however we identified two testicles, which are divided in three segments each one, separated by a thin epithelial membrane (Wägele, 1992; Schlatt \& Ehmcke, 2014).

This difference in $E$. attenuata may be determined by, the reduced and elongated body, which led to the merge of three testicles in one compartmentalized, a process that would not be rare in the evolutionary record (Roosen-Runge 1969, 1997; White-Cooper \& Bausek, 2010; Schlatt \& Ehmcke, 2014).

The rest of the internal anatomy agrees with other groups of isopods. The presence of a pair of nerve cords in the ventral region and a digestive tube in its middle portion that travels throughout the body, six hepatopancreas tubules that run in a parallel manner to the digestive tract (Holdich, 1971).

Regarding the external reproductive structures, E. attenuata does not seems to be very different from the other isopods; it possesses a pair of hemipenises between the end of the last body segment and at the base of the pleon, and a pair of ornamented stylets behind the second pair of pleopods, structures that allow fertilization (Wilson, 1991).

The existence of all phases of spermatogenesis, from spermatogonia to spermatozoids, which were observed at different times of the year and in different sizes of males, confirms the existence of a continuous reproductive cycle. We also confirmed that the spermatozoids of $E$. attenuata lack flagella, as the rest of isopods, yet the spermatozoids of this species are very elongated, and this is confirmed by positive reaction to $\mathrm{H}-\mathrm{E}$ staining, as the acrosome can be seen fully dyed by haematoxylin with purple colouring (Wilson, 1991; Wägele 1992). After observing the maturation of gametes occurs during the whole year, we conclude that $E$. attenuata has a continuous reproductive cycle; which is important due to the ecological role that it comprehends. Additionally, the description for the first time of the reproductive characteristics of this isopod is important, because the biological characteristics of these crustaceans have been neglected, thus, it is necessary to update and extend the morphological and histological information of these organis$\mathrm{ms}$, conforming a parameter for new studies of other isopod species and stablishing a basis for further comparatives on the evolutionary on ecological relationships of isopod and other groups of crustaceans and arthropods.

\section{ACKNOWLEDGEMENTS}

We are grateful to Ana Isabel Bieler, of the Microcine laboratory, Faculty of Sciences at UNAM, for obtaining photomicrographies; Berenit Mendoza, Biology Institute, UNAM, for assistance with SEM images; Ricardo Gaspar and Alan González, and the enthusiasts fishermen Luis and Jorge Luis Díaz, from Tamiahua lagoon for assistance with field-work.
To the CONACYT-DAAD joint program for granting the Scholarship number 471064 to H.E. Reyes-Aldana for the studies in the master program Evolution, Ecology and Systematics at the LMU Munich.

\section{REFERENCES}

Álvarez, F., J. L. Bortolin \& J. T. Heög. 2010. Anatomy of virgin and mature externae of Loxothylacus texanus, parasitic on the dark blue crab Callinectes rathbunae (Crustacea: Cirripedia: Rhizocephala: Sacculinidae). Journal of Morphology 271: 190-199. DOI: 10.1002/ jmor.10790.

Austin, B. \& D. A. Austin. 1989. Methods for the microbiological examination of fish and shellfish. Ellis Horwood Limited, England. 317 p.

BeLL, T. A. \& D. V. LIGHTner. 1988.A handbook of normal Penaeid shrimp histology. Lawrence, KS: World Aquaculture Society Press, USA. $114 \mathrm{p}$.

Bortolini-Rosales, J. L., H. Reyes-Aldana \& M. A. Gómez-Ponce. 2016. New records of Erichsonella attenuata (Isopoda: Valvifera: Idoteidae) in the Gulf of Mexico. Revista Mexicana de Biodiversidad 87: 523526.DOI: 10.1016/j.rmb.2016.03.004

Boström, C. \& J. MatTlLa. 2005. Effects of Isopod Grazing: An Experimental Comparison in Temperate (Idotea balthica, Baltic Sea, Finland) and Subtropical (Erichsonella attenuata, Gulf of Mexico, U.S.A.) Ecosystems. Crustaceana 78(2): 185-200. DOI: 10.1163/1568540054020541

Brusca, R. C., W. Moore \& S. M. Shuster. 2016. Invertebrates. Sinauer Associates Sunderland, Massachusetts, USA. 1104 p.

CSONKA, D., K. Halasy \& E. HoRnung. 2015. Histological studies of the marsupium of two terrestrial isopods (Crustacea: Isopoda, Oniscidea). ZooKeys 51:81-92. DOl: 10.3897/zookeys.515.9401

Encina, L. \& C. Granado-Lorencio. 1997. Seasonal changes in condition, nutrition, gonad maturation and energy content in barbel, Barbus sclateri, inhabiting a fluctuating river. Environmental Biology of Fishes 50(1): 75-84. DOI: 10.1023/A:1007381414397

Fredette, J. T., R. Diaz, J. Montfranas \& R. Orth. 1990. Secondary Production within a seagrass bed (Zostera marina and Ruppiamaritima) in lower Chesapeake Bay. Estuaries 13(4): 431-440. D0I: $10.2307 / 1351787$

HoLDICH, D. M. 1971. Changes in physiology, structure and histochemistry occurring during the life history of the sexually dimorphic isopod Dynamene bidentata (Crustacea: Peracarida). Marine Biology 8: 3547. DOI: $10.1007 / \mathrm{BF} 00349343$

Jaglarz, M. K., J. KubRakIEWICZ \& S. BiLINSKI. 2014. The ovary structure and oogenesis in the basal crustaceans and hexapods. Possible phylogenetic significance. Arthropod structure \& development 43(4): 349-360. DOI: 10.1016/j.asd.2014.05.003

Johnson, P. T. 1980. Histology of the blue crab: Callinectes sapidus: a model for the Decapoda. Praeger, New York. 440 p.

Johnson, W. S., M. Stevens \& L. Watling. 2001. Reproduction and development of marine peracaridans. Advances in Marine Biology 39: 105-260. DOI: 10.1016/S0065-2881(01)39009-0 
KAUTSKY, N. 1982. Quantitative studies on gonad cycle, fecundity, reproductive output and recruitment in a Baltic Mytilus edulis population. Marine Biology 68(2): 143-160. D0I: 10.1007/BF00397601

KensLey, B., W. G. Nelson \& M. Schotte. 1995. Marine isopod biodiversity of the Indian River lagoon, Florida. Bulletin of Marine Science 57(1): 136-142.

Poore, G. \& M. Schotte. 2014. Erichsonella Benedict in Richardson, 1901. In: Schotte, M., C.B. Boyko, N.L. Bruce, G.C.B. Poore, S. Taiti \& G.D.F. Wilson (eds.). 2014. World Marine, Freshwater and Terrestrial Isopod Crustaceans database. National Museum of Natural History Smithsonian Institution, Washington D.C, USA. Also available at: http://www.marinespecies.org/aphia.php?p=taxdetaiIs\&id=157886 (downloaded May 22, 2015)

PIRÉs, A. N. S. 1984. Taxonomic revision and phylogeny of the genus Erichsonella with a discussion on Ronalea (Isopoda, Valvifera). Journal of Natural History 18(5): 665 -683. D0I: $10.1080 / 00222938400770571$

Romero-Rodriguez J. \& R. Román-Contrearas. 2008. Aspects of reproduction of Bopyrinellathorii (Richardson, 1904) (Isopoda, Bopyridae), a branchial parasite of Thor floridanus Kinsley, 1878 (Decapoda, Hippolytidae) in Bahía de la Ascención, mexican caribbean. Crustaceana 81(10): 1201-1210. DOI: 10.1163/156854008X374522

Roosen-Runge, E. C. 1969. Comparative aspects of spermatogenesis. Biology of reproduction 1(Supplement 1): 24-39. D0I:10.1095/biolreprod1.Supplement_1.24

Roosen-Runge, E. C. 1997. The process of spermatogenesis in animals. Cambridge University Press, London, England. 214p.
RYER, C. H. \& R. J. ORTH. 1987. Feeding Ecology of the Northern Pipefish, Syngnathusfuscus, in a Seagrass Community of the Lower Chesapeake Bay. Estuaries 10(4): 330-336. DOI: 10.2307/1351891

SCHLAтT, S. \& J. EHмсKE. 2014. Regulation of spermatogenesis: an evolutionary biologist's perspective. Seminars in cell \& developmental biology 29: 2-16. DOI: 10.1016/j.semcdb.2014.03.007

Schuldt, M. 1993. Ovarian cycle of Probopyrus ringueleti (Verdi y Schuldt, 1998) (Isopoda: Epicaridea: Bopyridae). Gayana zool 57(1): 89-104.

Sheehan, D. C. \& B. B. Hrapchak. 1980. Theory and practice of histotechnology. The C. V. Mosby Company, USA. 481 p.

Shyamasundari, K., Hanumantha, C. Jalaja \& A. Mary. 1987. First studies on the anatomy, histology and histochemistry of the female reproductive system of a parasitic isopod Nerocilaserra Schioedte and Meinert, 1881 from fishes of Waltair coast. Revista Ibérica de Parasitología 47: 301-307.

WäGELE, J. W. 1992. Isopoda. In: Humes, G.H. (ed.). Microscopic Anatomy of Invertebrates, Crustacea, Vol. 9. University of Michigan-Wiley, USA. $672 \mathrm{p}$.

WarBuRG, M. R. 2013. Evolutionary biology of land isopods. Springer Science \& Business Media, Berlin, Germany. $161 \mathrm{p}$.

White-Cooper, H. \& N. Bausek. 2010. Evolution and spermatogenesis. PhiIosophical Transactions of the Royal Society of London B: Biological Sciences 365 (1546): 1465-1480. D0I: 10.1098/rstb.2009.0323

WILSON, G. 1991. Functional morphology and evolution of isopod genitalia. In: Bauer R. \& J. Martin (ed.). Crustacean sexual biology. Columbia University Press, New York. 355p. 